\title{
Ultrahigh-resolution 3D full-field optical coherence micropscopy of the pulmonary airways ex vivo
}

\author{
Linbo Liu*, William Oh, Brett Bouma, Steven Rowe, Guillermo Tearney \\ From 2nd Scientific Meeting of the Head and Neck Optical Diagnostics Society \\ San Francisco, CA, USA. 23-24 January 2010
}

Visualizing the respiratory mucosa in pulmonary airways at the sub-cellular level could yield new insights into pathogenesis of many important diseases. However, current imaging modalities to study the respiratory mucosa lack the required resolution to visualize critical subcellular detail such as nuclei and respiratory epithelial cilia.

Full-field optical coherence microscopy (FFOCM) is an emerging technique capable of providing reflectance images in situ with high spatial resolution in all three dimensions.We have developed a FFOCM with an axial sectioning thickness of $1 \mu \mathrm{m}$ and a high transverse resolution of $0.6 \mu \mathrm{m}$. The three-dimensional field of view was $256(\mathrm{H}) \times 256(\mathrm{~W}) \times 400(\mathrm{D}) \mu \mathrm{m}$. Threedimensional images of formalin-fixed, sectioned porcine bronchial segments were obtained immediately ex vivo. Images were compared to H\&E stained histology at corresponding sites. Pilot images on fixed human airways from individuals with cystic fibrosis (CF) and Chronic Obstructive Pulmonary Disease (COPD) were also acquired.

Individual epithelial cells and goblet cells, including their subcellular morphologies, were easily seen. Crosssectional views showed gland ducts containing mucus, cilia, the periciliary layer (PCL), and nuclei. Threedimensional rendering of the trachea showed the presence of mucus droplets directly above non-ciliated goblet cells, tethered to the surface of these cells by a thin adherent mucus strand.

Our results demonstrate the potential of FFOCM to provide detailed microstructural imaging of pulmonary airways without administration of a contrast medium. The future development of a probe for in vivo

\footnotetext{
$\overline{\text { Wellman Centre for Photomedicine, Massachusetts General Hospital, Boston, }}$ USA
}

monitoring of mucociliary transport, gland function, and airway surface liquid (ASL) depth could provide new avenues for improving our understanding of respiratory mucosal pathophysiology and enable longitudinal assessment of the response to novel drugs.

Published: 29 October 2010

doi:10.1186/1758-3284-2-S1-010

Cite this article as: Liu et al:: Ultrahigh-resolution 3D full-field optical coherence micropscopy of the pulmonary airways ex vivo. Head \& Neck Oncology 2010 2(Suppl 1):010.

Submit your next manuscript to BioMed Central and take full advantage of:

- Convenient online submission

- Thorough peer review

- No space constraints or color figure charges

- Immediate publication on acceptance

- Inclusion in PubMed, CAS, Scopus and Google Scholar

- Research which is freely available for redistribution

Submit your manuscript at www.biomedcentral.com/submit 